\title{
Plant Growth Regulators in the in Vitro Cultivation of Acmella oleracea (L.)
}

\author{
Nastassja Kimberlly Lima, Eloisa Schneider da Silva, Rayane Monique Sete da Cruz \\ Universidade Paranaense - UNIPAR, Campus III. Avenida Tiradentes, 3240 - Jardim Paraíso, \\ Umuarama, PR, Brazil
}

\section{Pedro Henrique Riboldi Monteiro}

Universidade Federal dos Vales do Jequitinhonha e Mucuri - UFVJM, Campus JK. Rodovia MGT 367 - Km 583, nº 5.000 - Alto da Jacuba, Diamantina, MG, Brazil

Glacy Jaqueline da Silva (corresponding author)

Universidade Paranaense - UNIPAR, Campus III. Avenida Tiradentes, 3240 - Jardim Paraíso, Umuarama, PR, Brazil.

Received: Apr. 16, 2020

Accepted: June 10, 2020

Published: June 15, 2020

doi:10.5296/jas.v8i2.16863

URL: https://doi.org/10.5296/jas.v8i2.16863

\begin{abstract}
Acmella oleracea is a tropical plant, typical of the northern region of Brazil. The species belongs to the Asteraceae family and has great therapeutic, pharmacological and industrial potential. A limiting factor for the production of this species on a large scale is the short life cycle. The tissue culture programs use synthetic hormones based on cytokinins, such as kinetin and benzylaminopurine (BAP) and auxins such as naphthalene acetic acid (ANA). The objective of this research was to evaluate the effect of growth regulators on the production of Acmella oleracea "in vitro". The experimental test was carried out with control (C), without the addition of growth regulators and five treatments, composed of: (T1) 0.1; (T2) 0.3 ; (T3) $0.5 \mathrm{mg} \mathrm{L}^{-1}$ kinetin; (T4) $0.1 \mathrm{mg} \mathrm{L}^{-1}$ of BAP and ANA; (T5) $0.5 \mathrm{mg} \mathrm{L}^{-1}$ of BAP and ANA. The experimental design was a completely randomized block in a factorial arrangement with six treatments, three blocks and twenty-five repetitions per block. The evaluated parameters were: germination, root formation, aerial part length, root length, aerial part fresh mass and root fresh mass, aerial part dry mass and root dry mass. The data obtained were subjected to analysis of variance $(\mathrm{p}<0.05)$ and compared using the Tukey test. The results showed that kinetin positively contributed to seed germination and aerial part dry
\end{abstract}


mass development. Treatment 1 had the best results for the parameters root length, shoot length and root dry mass.

Keywords: Asteraceae, 6-benzylaminopurine, Jambu, kinetin, medicinal plants

\section{Introduction}

Acmella oleracea is a species with wide distribution in tropical regions, found in South America, Africa and Asia, belonging to the Asteraceae family and genus Acmella, which is composed of about 30 species. In the northern region of Brazil the species is popularly known as Jambu and is generally cultivated by family farmers (Favoreto and Gilbert, 2010).

Jambu is an annual herbaceous plant that can grow to $40 \mathrm{~cm}$ in height in adulthood. The species has great importance in the economy of family farmers, but plantations are not performed on a large scale. Cultivation occurs mainly in the areas close to the residences, in order to meet own consumption. Only the surplus is traded when in excess, at vegetable fairs (Anderberg et al., 2007; Favoreto and Gilbert, 2010; Homma et al., 2011). The economic value attributed to the species for the local population is found in the purpose of use, which is generally applied to regional cuisine, in which it is considered as one of the main ingredients in the preparation of typical dishes, such as "tacacá" and "pato no tucupi", as well as an ornamental plant in horticulture and for medicinal purposes (Anderberg et al., 2007).

The ethnocultural knowledge about the properties of A. oleracea aroused the interest of researchers, who discovered that the plant has a bioactive compound in the leaves, stems and flowers, the $\mathrm{N}$-isobutylamide of deca-2,6,8-trienic acid (2E, 6Z, 8E), known as spilantol (Favoreto and Gilbert, 2010). This resulted in the growing interest of the medicinal and cosmetic industries, which in recent years has invested in products that use jambu as a raw material. The literature shows that the patents developed with this compound have as anesthetic, antiseptic, anti-wrinkle, anti-inflammatory, antifungal, antimicrobial, gynecological and is sold as a medicine and cosmetic in several products on the market (Favoreto and Gilbert, 2010; Homma et al. 2011; Almeida and Gama, 2014).

With the technical-scientific discoveries about the potential for pharmacological use for medicinal and cosmetic treatments, a concern was created with the production of A. oleracea on a large scale to meet the demand of the industrial sector. However, there was little practical evolution in the plant cultivation process. Another limiting factor for large-scale production would be adaptation outside the equatorial regions, that is, in the subtropical and temperate regions. These are the regions where the country's major industrial centers are concentrated (Cavalcanti, 2008; Tiwari et al., 2011).

Therefore, there is a need to obtain high quality plants, with the same pattern of growth and development as in the origin regions. An alternative to overcome this problem would be the in vitro cultivation of the species. An alternative to overcome this problem would be the in vitro cultivation of the species. This technique makes it possible to obtain plants with high quality, in addition to allowing the production of seedlings at any time of the year, resulting in large amounts of plant tissue in a short period of time, with disease-free plants, as they are grown under light and fully controlled temperature (Hussain et al., 2012). 
However, one of the challenges for this technique and species is that the use of explants, leaves and shoots of A. oleracea, in tissue culture is a slow process. In addition there is a need to determine culture media for each species of regenerated tissue, increasing the cost of production (Singh et al. 2009; Pandey, Agrawal, 2009; Yadav et al. 2012). Among the numerous culture media, the most used is that of Murashige and Skoog, known worldwide as MS media (Yadav and Singh, 2010). The main limiting factors for tissue culture production are the determination of the appropriate standards for growth regulators (Quisen and Angelo, 2008; Colombo et al. 2010).

Growth regulators are synthetic plant hormones, which participate in the control of plant growth, and which are used in tissue culture in order to induce the development of explants (Dias, 2019). The search for the combination of auxins and cytokinins in the growth and development of plants is important, since auxins help in the elongation and cell division for the root formation, while cytokinins inhibit the roots and stimulate protein and enzymatic activity. Often endogenous auxins and cytokinins are sufficient for the development of plant tissues. In other cases, such as A. oleracea, it is necessary to add these regulators, exogenously (Durbak et al. 2012).

The literature shows the efficiency of the use of synthetic hormonal products based on cytokinins such as kinetin, benzylaminopurine (BAP) and the base of auxins such as naphthalenoacetic acid (ANA), in cultures of Brassica oleracea subsp. Italic (broccoli) cv. 'Green Marvel' (Ravanfar et al., 2009), Vitis ssp. (Alizadeh et al., 2012), Scoparia dulcis L. (Zeya and Trivedi, 2019), Pyrus ssp. and Malus ssp. (Camargo et al., 2018), among others. These plant regulators can be used individually or in combinations with each other or in mixtures with other compounds of biochemical nature, such as amino acids, micronutrients and vitamins (Castro and Vieira, 2001).

For this reason, the objective of this work was to verify the influence of growth regulators on the germination and development of A. oleracea in an in vitro culture system, in order to obtain plants in a short period of time, in addition to optimizing the form of cultivation.

\section{Materials and Methods}

The studies were carried out in the Laboratory of Molecular Biology and Laboratory of Vegetal Tissue Cultures of Paranaense University (UNIPAR), in the city of Umuarama, Paraná state, Brazil. The utilized seeds were acquired commercially from rural producers from the city of Amapá - AP, Brazil.

\subsection{Treatments and Experimental Design}

The seeds were submitted to an asepsis process in a laminar flow where they were kept for 3 minutes in a solution with distilled water and neuter detergent. Next, they were immersed in ethylic alcohol at $70 \%$, followed by 5 minutes in sodium hypochlorite at $5 \%$ under constant agitation. After this period, four successive washings were performed with deionized water and then autoclaved. For the in vitro culture, the seeds from the asepsis were seeded in transparent glass flasks containing $80 \mathrm{~mL}$ of MS culture medium (Murashige and Skoog, 1962 ), added of $30 \mathrm{~g} / \mathrm{L}$ of sucrose, $0.05 \mathrm{~g} / \mathrm{L}$ of ascorbic acid, $6.5 \mathrm{~g} / \mathrm{L}^{-1}$ of agar with $\mathrm{pH}$ 
adjusted to 5.8, and growth regulators that varied according to each treatment. The evaluated treatments were: control (C) without growth regulator addition, (T1) $0.1 \mathrm{mg} / \mathrm{L}^{-1}$ of kinetin; (T2) $0.3 \mathrm{mg} / \mathrm{L}^{-1}$ of kinetin; (T3) $0.5 \mathrm{mg} / \mathrm{L}^{-1}$ of kinetin; (T4) $0.1 \mathrm{mg} / \mathrm{L}^{-1}$ of BAP $+0.1 \mathrm{mg} / \mathrm{L}^{-1}$ of ANA; (T5) $0.5 \mathrm{mg} / \mathrm{L}^{-1}$ of BAP $+0.5 \mathrm{mg} / \mathrm{L}^{-1}$ of ANA. The flasks containing culture medium were autoclaved at $121{ }^{\circ} \mathrm{C}$ for 20 minutes.

After seeding seed in a sterile laminar flow, the flasks were closed with transparent autoclaved plastic lids, sealed with PVC film and placed in a growth chamber. All the treatments had the same conditions: 24h-photoperiod with fluorescent white light and light intensity of 3600 lux (measured by a lux meter) at the temperature of $25+-2^{\circ} \mathrm{C}$. The experiment was carried out in a completely random design with 6 treatments, 3 (three) replications and 25 (twenty-five) flasks by replications, totaling 75 (seventy-five) flaks per treatment. Each flask was inoculated with one seed.

During culture setting, evaluations were done in two distinct periods (48 days and 90 days). In the initial evaluation, at 48 days, data on the percentage of germination, stem formation, abnormal seedlings, percentage of plant oxidation and contamination rate were determined. The contamination criterion was the presence of fungi and bacteria. In the final evaluation, the aerial part length (APL) and root length (RL) was obtained using a pachymeter. The aerial part fresh mass (APFM) and the root fresh mass (RFM) were obtained from weighing the seedlings in an analytical scale; next, the material was dried at ambient temperature until constant mass to obtain the aerial part dry mass (APDM) and root dry mass (RDM).

\subsection{Statistical Analysis}

The data were submitted to analysis of variance $(\mathrm{p}<0.05)$ and compared by Tukey's test $(\mathrm{p}<$ $0.05)$ utilizing the statistical program SPSS (2011).

\section{Results and Discussion}

\subsection{Germination Process}

The results proved statistically that the addition of hormones had effects, for the parameters of germinated and non-germinated plants, when compared to the control. However, when the other parameters: abnormal plants, callus formation and oxidized plants were observed, there were no significant differences, because no seedling showed these symptoms (Table 1). 
Table 1. Development analysis of Acmella oleracea regeneration on day 48 of culture under 5 treatments (T) and control (C), evaluating the parameters: Germinated plants (GP); Root formation (RF); Contaminated plants (CP); Non-germinated plants (NGP); Abnormal plants (AP); Callus formation (CF); Oxidized plants (OP)

\begin{tabular}{l|l|l|l|l|l|l|l}
\hline & $\begin{array}{l}\text { Germinated } \\
\text { Plant }\end{array}$ & $\begin{array}{l}\text { Root } \\
\text { Formation }\end{array}$ & $\begin{array}{l}\text { Comtaminated } \\
\text { Plants }\end{array}$ & $\begin{array}{l}\text { Non-Germinated } \\
\text { Plants }\end{array}$ & $\begin{array}{l}\text { Abnormal } \\
\text { Plants }\end{array}$ & $\begin{array}{l}\text { Callus } \\
\text { Formation }\end{array}$ & $\begin{array}{l}\text { Oxidized } \\
\text { Plants }\end{array}$ \\
\hline $\mathrm{C}$ & $56.3 \pm 0.3^{\mathrm{c}}$ & $53.0 \pm 2.0^{\mathrm{a}}$ & $2.3 \pm 0.3^{\mathrm{a}}$ & $16.3 \pm 0.3^{\mathrm{a}}$ & 0 & 0 & 0 \\
\hline $\mathrm{T} 1$ & $65.0 \pm 0.0^{\mathrm{a}}$ & $63.0 \pm 1.0^{\mathrm{a}}$ & $1.0 \pm 0.0^{\mathrm{a}}$ & $9.3 \pm 0.9^{\mathrm{b}}$ & 0 & 0 & 0 \\
\hline $\mathrm{T} 2$ & $61.6 \pm 1.4^{\mathrm{b}}$ & $52.0 \pm 3.2^{\mathrm{a}}$ & $1.0 \pm 0.0^{\mathrm{a}}$ & $11.7 \pm 1.2^{\mathrm{b}}$ & 0 & 0 & \\
\hline $\mathrm{T} 3$ & $63.3 \pm 1.2^{\mathrm{ab}}$ & $56.3 \pm 3.4^{\mathrm{a}}$ & $2.0 \pm 0.0^{\mathrm{a}}$ & $9.3 \pm 0.3^{\mathrm{b}}$ & 0 & 0 & 0 \\
\hline $\mathrm{T} 4$ & $62.3 \pm 0.6^{\mathrm{ab}}$ & $57.3 \pm 4.2^{\mathrm{a}}$ & $2.3 \pm 0.9^{\mathrm{a}}$ & $10.3 \pm 1.7^{\mathrm{b}}$ & 0 & 0 & 0 \\
\hline $\mathrm{T} 5$ & $62.0 \pm 0.0^{\mathrm{b}}$ & $53.3 \pm 6.6^{\mathrm{a}}$ & $11.3 \pm 0.3^{\mathrm{a}}$ & $11.3 \pm 0.3^{\mathrm{b}}$ & 0 & 0 & 0 \\
\hline
\end{tabular}

Average \pm standard error. Averages followed by the same letter in the column do not differ statistically from each other by Tukey's test $(\mathrm{p} \leq 0.05)$.

Seed germination occurred from the third day after inoculation. Cardoso and Garcia (1997) reported that the jambu starts the germination stage at 7 days after planting in soil. This can be explained by the possible genetic variability of this plant in relation to the germination stage. The result obtained in this experiment is not different from that found in initial germination tests on germitest paper (data not shown). This makes us believe that the culture medium did not influence the germination initiation process. This result was similar to that found by Jamaleddine et al., 2011, when he performed the same process in Artemisia annua.

The use of growth regulators increased the germination rate of A.oleraceae seeds. Treatments $1\left(0,1 \mathrm{mg} / \mathrm{L}^{-1}\right.$ of kinetin), $3\left(0,5 \mathrm{mg} / \mathrm{L}^{-1}\right.$ of kinetin $)$ and $4\left(0,1 \mathrm{mg} / \mathrm{L}^{-1}\right.$ of $\mathrm{BAP}+0,1 \mathrm{mg} / \mathrm{L}^{-1}$ of ANA) were more significant when compared to the control, which presented the worst index. This represented a gain in twinning that varied between 9 to $15 \%$ between treatments 4 and 1 respectively. This result was also confirmed in evaluations on the hormones effect on the germination of Lotus corniculatus L., where Nikolic et al. (2006) reported that additions of growth regulators, by tissue culture, has the ability to interfere in the germination potential. With that, we can infer that the addition of growth regulators may be favorable in the germination of Asteraceae family species. Plant regulators have an influence on various plant organs and tissues. However, the effect depends on the species, the stage of development, the concentration, the interaction between regulators and various environmental factors (Taiz et al., 2017).

Cytokinin treatments obtained the highest germination rates. The best explanation for this positive effect is correlated with the environmental conditions to which these treated seeds were subjected. Cytokinins are generally not reported to be essential for the seed germination process, however, when subjected to the action of light, phytochrome B-type photoreceptors are activated, making hormonal regulators necessary, since cytokinins are important signallers and activators metabolic pathways, and which helps to induce the germination process (Fankhauser, 2002). 


\subsection{Plant Development}

When we observed the results of the development analysis of Acmella oleracea regeneration, at 90 days of cultivation, there was a statistical difference for all parameters evaluated (table 2). The variables that showed a difference between treatments and control, proving the effects in promoting growth via the application of hormones were: root fresh mass (RFM), the aerial part fresh mass (APFM) and aerial part dry mass (APDM).

Table 2. Development analysis of Acmella oleracea regeneration at 90 days of culture under 5 treatments $(\mathrm{T})$ and control $(\mathrm{C})$, evaluating the parameters: Root fresh mass (RFM); Aerial part fresh mass (APFM); Root length (RL); Aerial part length (APL); Root dry mass (RDM); Aerial part dry mass (APDM)

\begin{tabular}{ccccccc}
\hline T & RFM & APFM & RL & APL & RDM & APDM \\
\hline C & $3.3 \pm 0.2^{\mathrm{c}}$ & $12.6 \pm 1.1^{\mathrm{b}}$ & $20.1 \pm 0.6^{\mathrm{a}}$ & $14.7 \pm 0.3^{\mathrm{a}}$ & $0.3 \pm 0.0^{\mathrm{a}}$ & $0.2 \pm 0.0^{\mathrm{c}}$ \\
$\mathrm{T} 1$ & $1.4 \pm 0.1^{\mathrm{d}}$ & $11.4 \pm 1.1^{\mathrm{c}}$ & $17.4 \pm 0.8^{\mathrm{b}}$ & $13.3 \pm 0.3^{\mathrm{b}}$ & $0.1 \pm 0.0^{\mathrm{d}}$ & $0.1 \pm 0.0^{\mathrm{c}}$ \\
$\mathrm{T} 2$ & $3.0 \pm 0.2^{\mathrm{c}}$ & $12.6 \pm 1.2^{\mathrm{b}}$ & $10.8 \pm 0.6^{\mathrm{c}}$ & $12.8 \pm 0.3^{\mathrm{bc}}$ & $0.2 \pm 0.0^{\mathrm{c}}$ & $0.2 \pm 0.0^{\mathrm{c}}$ \\
$\mathrm{T} 3$ & $4.7 \pm 0.4^{\mathrm{ab}}$ & $11.3 \pm 1.8^{\mathrm{c}}$ & $11.4 \pm 0.4^{\mathrm{c}}$ & $13.4 \pm 0.1^{\mathrm{b}}$ & $0.3 \pm 0.0^{\mathrm{abc}}$ & $0.6 \pm 0.0^{\mathrm{b}}$ \\
$\mathrm{T} 4$ & $4.2 \pm 0.3^{\mathrm{bc}}$ & $15.8 \pm 1.1^{\mathrm{a}}$ & $9.6 \pm 0.4^{\mathrm{cd}}$ & $12.5 \pm 0.3^{\mathrm{bc}}$ & $0.2 \pm 0.0^{\mathrm{bc}}$ & $0.7 \pm 0.0^{\mathrm{a}}$ \\
$\mathrm{T} 5$ & $5.5 \pm 0.4^{\mathrm{a}}$ & $12.7 \pm 1.1^{\mathrm{b}}$ & $8.4 \pm 0.3^{\mathrm{d}}$ & $12.0 \pm 0.2^{\mathrm{d}}$ & $0.3 \pm 0.0^{\mathrm{ab}}$ & $0.6 \pm 0.0^{\mathrm{b}}$ \\
\hline
\end{tabular}

Average \pm standard error. Averages followed by the same letter in the column do not differ statistically from each other by Tukey's test $(p \leq 0.05)$.

The T4 produced the highest amount of APFM. This indicates that this treatment has potential in the tissue culture programs for the production of natural chemical compounds, since this is an object of desire within the industrial sector for this plant. This statement is determined by the response of the addition of $0.1 \mathrm{mg} / \mathrm{L}^{-1}$ of BAP and $0.1 \mathrm{mg} / \mathrm{L}^{-1}$ of ANA, in treatment $\mathrm{T} 4$, which presented the best result regarding the APFM and APDM.

The increase in APFM and APDM part can be explained by the mode of action of these hormones, which act synergistically in cell division and plant regeneration in vitro, since cytokinins can act as a secondary messenger in regulating the formation of sprouts by auxins (Faiss et al., 1997; Fatima et al., 2011).

Studies on the combination of auxins and cytokinins in plant growth and development are extensive, so the results obtained in this experiment are in line with those found by Joshi et al. (2003) and Araújo et al. (2015).

From the results obtained in the previous parameters, we can explain the values obtained for 
RFM, in which the best treatment was the number T5 $\left(0.5 \mathrm{mg} / \mathrm{L}^{-1}\right.$ of BAP and $0.5 \mathrm{mg} / \mathrm{L}^{-1}$ of ANA), followed by $\mathrm{T} 3\left(0.5 \mathrm{mg} / \mathrm{L}^{-1} \mathrm{CIN}\right)$. The combination of the hormones BAP and ANA in in vitro cultures has proven efficiency, since the joint action of these hormones potentiates the seedling multiplication process. However, the shoots present a very small lengthening of the aerial part, becoming difficult to individualize (Medeiros et al., 2001). This validates the results obtained in the T5 treatment, which produced the second largest amount of APFM and RFM.

Kinetins act in the formation of lateral roots and it is widely studied and detailed, as observed in the literature (Thimann, 1936; Debi et al., 2005). Studies with rice roots show that kinetin is very important in all lateral roots formation stages, providing an increase in fresh mass (Debi et al., 2005), according to the value observed in treatment $\mathrm{T} 3$, plus $0.5 \mathrm{mg} / \mathrm{L}^{-1}$ of CIN.

The T5 treatment $\left(0.5 \mathrm{mg} / \mathrm{L}^{-1}\right.$ of BAP and 0.5 of ANA mg/ $\left.\mathrm{L}^{-1}\right)$ was the one that produced the largest amount of RFM, however, when the RL or APL parameters were observed, this treatment showed the worst result statistically for both characteristics. This result can be explained by the large amount of lateral roots produced, which increased the weight of the fresh mass, however it restricted the elongation of the roots. The result of the present study was similar to that found by Gatita and Almeida (2003) and by Haque et al. (1997), which promoted the development of root length in tomato and garlic seedlings respectively.

The best results for APL and RL were observed in the control, however, these results are not different from those described in some literature, which report that the best results for the root length parameter for Rubus sp. (Ebony) and Physalis peruviana, occurred in the absence of growth regulators in culture medium (Villa et al., 2005; Chaves et al., 2005). This is an interesting and useful factor, as it provides a reduction in laboratory costs with materials within a tissue culture program. That is, the absence of growth regulators, can be adopted when the tissue culture programs need to obtain the parameters root length, dry root mass, and shoot length.

The root dry mass parameter showed no statistical difference between the control (without the addition of growth regulators) and the T3 and T5 treatments $\left(0.5 \mathrm{mg} / \mathrm{L}^{-1}\right.$ of kinetin; 0.5 $\mathrm{mg} / \mathrm{L}^{-1}$ of BAP $+0,5 \mathrm{mg} / \mathrm{L}^{-1}$ of ANA). This result can be explained by the combination of auxins and cytokinins that act synergistically or independently in the development of root cells. Thus, in the presence of both types, and also in the absence of adding these, the plant can supply its needs through the use of alternative routes to provide the best development and cell growth (Depuydt and Hardtke, 2011).

\section{Conclusion}

It was verified that in different concentrations, BAP and ANA had significant results in the formation of fresh root mass and fresh shoot mass. Kinetin positively contributed to seed germination and aerial part dry mass development. The control had the best results for the parameters root length, Aerial part length and root dry mass. The control (without growth regulator) was the one that obtained the best results in the main evaluations for obtaining tissue. For the production of plants in vitro on a large scale, it is recommended to use this treatment. 


\section{Acknowledgements}

The authors thank Universidade Paranaense, Programa de Pós-graduação em Biotecnologia Aplicada à Agricultura, Coordenação de Aperfeiçoamento de Pessoal de Nível Superior Brasil (CAPES), Fundação Araucária, and Conselho Nacional de Desenvolvimento Científico e Tecnológico $(\mathrm{CNPq})$ for the financial support and fellowship.

\section{References}

Alizadeh, M., Singh, S. K., \& Patel, V. B. (2012). Comparative performance of in vitro multiplication in four grape (Vitis spp.) rootstock genotypes. International Journal of Plant Production, 4(1), 41-50.

Almeida, L. S. D., \& Gama, J. R. V. (2014). Home gardens: structure, floristic composition and environmental aspects in area of rural settlement in Brazil's Amazon forest. Ciência Florestal, 24(4), 1041-1053. https://doi.org/10.5902/1980509816617

Anderberg, A. A, Baldwin, B.G., Bayer, R. G., Breitwieser, J., Jeffrey, C., Dillon, M. O., ... Watson, L. E. Compositae. In: Rohwer, J. G., \& Bittrich, V. (2007). The families and genera of vascular plants (Vol. 2). K. Kubitzki (Ed.). Berlin: Springer.

Araujo, R. F., Siqueira, D. L., \& Cecon, P. R. (2015). Multiplicação in vitro do abacaxizeiro 'smooth cayenne'utilizando benzilaminopurina (BAP) e ácido naftalenoacético (ANA). Ceres, 55(5).

Camargo, S. S. C. S., Meneguzzi, A., Gonçalves, M. J., Grimaldi, F., \& Rufato, L. (2018). In vitro morphogenesis from leaves fragments of pear and apple rootstocks. Plant Cell Culture \& Micropropagation, 14(2), 32-44.

Cardoso, M. O., \& Garcia, L. C. (1997). Jambu (Spilanthes oleracea L.). In: Cardoso, M. O. (1997). Hortaliças não-convencionais da Amazônia. Brasília: Embrapa, Serviço de Produção de Informação.

Castro, P. R., \& Vieira, E. L. (2001). Aplicações de reguladores vegetais na agricultura tropical (No. 631.8 C355a). Guaíba, BR: Editora Agropecuária.

Cavalcanti, V. M. S. (2008). Extração de espilantol de Spilanthes acmella var oleraceae com dióxido de carbono supercrítico. 2008. $p$ (Doctoral dissertation, Tesis ( $\mathrm{PhD}$ in Engenharia Química)-Universidade Estadual de Campinas, Campinas).

Chaves, A. D. C., Schuch, M. W., \& Erig, A. C. (2005). In vitro establishment and multiplication of Physalis peruviana L. Ciencia e Agrotecnologia (Brazil), 29(6), 1281-1287. https://doi.org/10.1590/S1413-70542005000600024

Colombo, L. A., de Assis, A. M., de Faria, R. T., \& Roberto, S. R. (2010). Establishing a protocol for in vitro multiplication of Philippine wax flower (Etlingera elatior) Jack RM $\mathrm{Sm} /$ Estabelecimento de protocolo para multiplicacao in vitro de Bastao-do-imperador (Etlingera elatior) Jack RM Sm. Acta Scientiarum. Agronomy, 32(4), 695-701. https://doi.org/10.4025/actasciagron.v32i4.4830 
Debi, B. R., Taketa, S., \& Ichii, M. (2005). Cytokinin inhibits lateral root initiation but stimulates lateral root elongation in rice (Oryza sativa). Journal of plant physiology, 162(5), 507-515. https://doi.org/10.1016/j.jplph.2004.08.007

Depuydt, S., \& Hardtke, C. S. (2011). Hormone signalling crosstalk in plant growth regulation. Current Biology, 21(9), R365-R373. https://doi.org/10.1016/j.cub.2011.03.013

Dias, J. P. T. (2019). Plant growth regulators in horticulture: practices and perspectives. Biotecnología Vegetal, 19(1), 3-14.

Durbak, A., Yao, H., \& McSteen, P. (2012). Hormone signaling in plant development. Current Opinion in Plant Biology, 15(1), 92-96. https://doi.org/10.1016/j.pbi.2011.12.004

Faiss, M., Zalubìlová, J., Strnad, M., \& Schmülling, T. (1997). Conditional transgenic expression of the ipt gene indicates a function for cytokinins in paracrine signaling in whole tobacco plants. The Plant Journal, 12(2), 401-415. https://doi.org/10.1046/j.1365-313X.1997.12020401.x

Fankhauser, C. (2002). Light perception in plants: cytokinins and red light join forces to keep phytochrome B active. Trends in Plant Science, 7(4), 143-145. https://doi.org/10.1016/S1360-1385(02)02228-8

Fatima, N., Ahmad, N., \& Anis, M. (2011). Enhanced in vitro regeneration and change in photosynthetic pigments, biomass and proline content in Withania somnifera L. (Dunal) induced by copper and zinc ions. Plant Physiology and Biochemistry, 49(12), 1465-1471. https://doi.org/10.1016/j.plaphy.2011.08.011

Favoreto, R., \& Gilbert, B. (2010). Acmella oleracea (L.) RK Jansen (Asteraceae)-Jambu. Revista Fitos, 5(01), 83-91.

Gatita, I. C., \& Almeida, J. (2003). Micropropagación del tomate de árbol (Cyphomandra betacea (Cav.) Sendtn.), Solanaceae silvestre usada en la alimentación humana. Revista Forest. Venez, 47(2), 9-13.

Haque, M. S., Wada, T., \& Hattori, K. (1997). High frequency shoot regeneration and plantlet formation from root tip of garlic. Plant Cell, Tissue and Organ Culture, 50(2), 83-89. https://doi.org/10.1023/A:1005973929862

Homma, A. K. O., Sanches, R. D. S., de Menezes, A. J. E. A., \& de Gusmão, S. A. L. (2011). Etnocultivo do jambu para abastecimento da cidade de Belém, estado do Pará. Embrapa Amazônia Oriental-Artigo em periódico indexado (ALICE), 10(20), 125-141.

Hussain, M. S., Fareed, S., Saba Ansari, M., Rahman, A., Ahmad, I. Z., \& Saeed, M. (2012). Current approaches toward production of secondary plant metabolites. Journal of pharmacy \& bioallied sciences, 4(1), 10. https://doi.org/10.4103/0975-7406.92725

Jamaleddine, Z. O., Lyam, P., Fajimi, O., Giwa, A., Aina, A., Lawyer, E. F., ... Odofin, W. T. (2011). In vitro growth response of Artemisia annua seeds to different concentrations of plant 
growth regulators. African Journal of Biotechnology, 10(77), 17841-17844. https://doi.org/10.5897/AJB10.1289

Joshi, I., Bisht, P., Sharma, V. K., \& Uniyal, D. P. (2003). In vitro clonal propagation of mature Eucalyptus F1 hybrid (Eucalyptus tereticornis Sm. $x$ E. grandis Hill ex. Maiden). Silvae Genetica, 52(3-4), 110-113.

Medeiros, D. D., Macedo, C. D., \& Alloufa, M. A. I. (2001). Efeito do $\mathrm{NaCl}$ sobre a multiplicação in vitro de abacaxizeiro (Ananas comosus (L.) Merril). Revista Brasileira de Fruticultura, Jaboticabal, 23(1), 1-5.

Murashige, T., \& Skoog, F. (1962). A revised medium for rapid growth and bio assays with tobacco tissue cultures. Physiologia Plantarum, 15(3), 473-497. https://doi.org/10.1111/j.1399-3054.1962.tb08052.x

Nikolić, R., Mitić, N., Miletić, R., \& Nešković, M. (2006). Effects of cytokinins on in vitro seed germination and early seedling morphogenesis in Lotus corniculatus L. Journal of plant growth Regulation, 25(3), 187. https://doi.org/10.1007/s00344-005-0129-4

Pandey, V., \& Agrawal, V. (2009). Efficient micropropagation protocol of Spilanthes acmella L. possessing strong antimalarial activity. In Vitro Cellular \& Developmental Biology-Plant, 45(4), 491. https://doi.org/10.1007/s11627-008-9184-4

Quisen, R. C., \& Ângelo, P. D. S. (2008). Manual de procedimentos do Laboratório de Cultura de Tecidos da Embrapa Amazônia Ocidental. Embrapa Amazônia Ocidental-Documentos (INFOTECA-E).

Ravanfar, S. A., Aziz, M. A., Kadir, M. A., Rashid, A. A., \& Sirchi, M. H. T. (2009). Plant regeneration of Brassica oleracea subsp. italica (Broccoli) CV Green Marvel as affected by plant growth regulators. African Journal of Biotechnology, 8(11).

Singh, S. K., Rai, M. K., Asthana, P., \& Sahoo, L. (2009). An improved micropropagation of Spilanthes acmella L. through transverse thin cell layer culture. Acta Physiologiae Plantarum, 31(4), 693-698. https://doi.org/10.1007/s11738-009-0280-9

Spss, I. I. B. M. (2011). IBM SPSS statistics for Windows, version 20.0. New York: IBM Corp, 440 .

Taiz, L., Zeiger, E., Møller, I. M., \& Murphy, A. (2017). Fisiologia e desenvolvimento vegetal. Artmed Editora.

Thimann, K. V. (1936). Auxins and the growth of roots. American Journal of Botany, 561-569. https://doi.org/10.1002/j.1537-2197.1936.tb09026.x

Tiwari, K. L., Jadhav, S. K., \& Joshi, V. (2011). An updated review on medicinal herb genus Spilanthes. Zhong xi yi jie he xue bao= Journal of Chinese integrative medicine, 9(11), 1170-1178. https://doi.org/10.3736/jcim20111103

Villa, F., Araújo, A. G. D., Pio, L. A. S., \& Pasqual, M. (2005). Multiplicação in vitro da amoreira-preta'Ébano'em diferentes concentrações de meio MS e BAP. Ciência $e$ 
Agrotecnologia, 29(3), 582-589. https://doi.org/10.1590/S1413-70542005000300011

Yadav, K., \& Singh, N. (2010). Micropropagation of Spilanthes acmella Murr. An important medicinal plant. Nature and Science, 8(9), 5-11.

Yadav, K., Singh, N., \& Verma, S. (2012). Plant tissue culture: a biotechnological tool for solving the problem of propagation of multipurpose endangered medicinal plants in India. Journal of Agricultural Technology, 8(1), 305-318.

Zeya, S., \& Trivedi, M. P. (2019). Effect of Rhustox on Micropropagation of Scoparia dulcis L. through Leaf Explants Culture. European Journal of Medicinal Plants, 1-14. https://doi.org/10.9734/ejmp/2019/v29i430162

\section{Copyright Disclaimer}

Copyright for this article is retained by the author(s), with first publication rights granted to the journal.

This is an open-access article distributed under the terms and conditions of the Creative Commons Attribution license (http://creativecommons.org/licenses/by/4.0/). 